\title{
Quality Of Life of Community Dwelling Elders in Lattakia City, Syrian
}

\section{Arab Republic}

\author{
Fatima Adnan Hallaj, Assistant Professor \\ Gerontological Nursing, Faculty of Medicine, Tishreen University-Syrian Arab Republic
}

\begin{abstract}
The quality of elders' lives is receiving increased attention with the demographic shift that has resulted in the greying of population. Objective: Determine the quality of life of community dwelling elderly in Lattakia. Setting: The study was carried out in all the fourteen health centers in Lattakia city, Syria. Subjects: The study subjects comprised 350 elderly persons. Tools: Three tools were used for data collection: The Socio-Demographic and Clinical Data Structured Interview Schedule, Health Promotion Behavior Check List, and the WHOQOL-OLD Scale. Results: The quality of life of $71.14 \%$ of elders was moderate where one fifth of them were had poor quality of life. Conclusion: The quality of life of community dwelling elderly was affected by age, comorbidities and health promotion activities. Recommendations: Implement health education programs for elders to improve their quality of life.
\end{abstract}

Keywords: Elderly; Quality Of Life; Health Promotion.

\section{Introduction}

The increase in life expectancy resulted in the rapid increase of aging population in the world ${ }^{(1)}$. This poses a great challenge to the responsible authorities to develop policies and interventions to promote health of this category of people. Nowadays the main focus is not only to increase lifetime, but also to create better physical and mental health i.e. improve the "quality of life"(2-4).

It has been well established that the aging process is associated with increased susceptibility to chronic conditions, decreased physical and mental functions, poorer energy, disability, and morbidity. Also, losses in life such as loss of job due to retirement, loss of partner, loneliness and inadequate social interactions, and impaired sexual activity are considered some of the causes that may result in medical, emotional, social and psychological problems which in turn affect elders' QOL ${ }^{(5-8)}$. As well, home and neighbourhood, life circumstances, poor economic, cultural, educational and health care conditions came on the top as factors that can take away QOL ${ }^{(9-12)}$.
Literature revealed that people are increasingly paying attention to healthy life expectancy, aiming for successful aging characterized by fulfilling an independent life while maintaining physical and mental health, improvement and maintenance of the maximum functional capacity in order to ensure that elderly people can remain independent in the environment in which they live during this extended period of old $\operatorname{age}^{(13-15)}$.

Adding life to years, not years to life, is the current agenda for productive and successful aging. World wide policies and programs on aging are increasingly focused on identifying ways to improve QOL and health status rather than just extending life $\operatorname{span}^{(1)}$. This can be achieved by adopting healthy life style that include maintain physical activity, healthy diet, rest and sleep, periodic medical checkup, avoid high risk behaviors, safety environment, and social and spiritual support ${ }^{(9,14,16)}$. Therefore, health promoting behaviors of older adults offer the potential for improving their health status and QOL as well as reducing the cost of health care and hospitalization ${ }^{(8,11)}$. 
Although QOL is an important marker of healthy aging, till now, no adequate attention is given in this respect in Syria. So, this study needs to throw light on the QOL of elderly people in Lattakia city, Syria. This will add valuable information which is important to guide health policy decisions and program for improving the QOL of elders, and could be used as a baseline for further studies for assessing other influential factors on the QOL in elderly population.

\section{Aim of the Study}

The aim of this study is to determine the quality of life of community dwelling elders in Lattakia city, Syrian Arab Republic.

\section{Research Question}

What is the quality of life status of community dwelling elders in Lattakia city, Syrian Arab Republic?

\section{Materials and Method}

\section{Materials}

Design: A descriptive study was used in this study.

Setting: The study was carried out in all 14 health care centers in Lattakia city, Syria. These centers are affiliated to the Health Administration in Lattakia Governorate, which is under the Ministry of Health. They are distributed on the city neighborhood (one center for each one), they provides services (free of charge) for elders through the geriatric clinic. These services include medical checkup, laboratory services, some assays, and provision of medications especially cardiovascular and hypoglycemic drugs for geriatric patients.

Subjects: The study subjects included 350 elders, they were selected from the 14 health care centers. From each centers 25 elders' aged 65 years and more, living in the community, able to communicate, and accept to participate in the study. Were selected using the systematic sampling technique.
Tools: Three tools were used to collect the study data:

\section{Tool I: Socio-demographic and Clinical} Data Structured Interview Schedule

It was developed by the researcher and included two parts:

1. Socio-demographic characteristics of the elders: such as age, sex, social status, level of education, occupation before retirement, source of income.

2. Clinical data: such as presence of chronic disease, hearing disorders, vision disorders, mobility problem, used assistive devices and medication used.

\section{Tool II: Health Promotion Behavior Check List}

This scale was developed and validated by WHO (Mick Power and Silke Schmidt on behalf of the WHOQOL-OLD Group) (2006) ${ }^{(17)}$, and used to assess the quality of life for elders.

It is composed of 24 questions that investigate six facets of 4 items each: the elders' sensory abilities; autonomy past, present and future activities; social participation; death and dying; intimacy.

The maximum score is 120 . The total score categories can be evaluated as the following manner: $\leq 24$ very bad, $>24-\leq 48$ bad, $>48-\leq 72$ moderate, $>72-\leq 96$ good, $>96-120$ very good.

\section{Tool III: The WHOQOL-OLD Scale}

This tool was developed by the researchers after literature reviewing and guided by Chan et al. $(2015)^{(36)}$. It was used to measure intimacy between the elderly home residents, which indicates the quality of their relationship. It consists of 17 items, each item had three possible responses: 0 (No), 1 (Sometimes), and 2 (Yes). The total score of the questionnaire ranged from 0 to 34. The higher score represents greater intimacy/affection. 


\section{Method}

- Official approvals from the competent authorities to carry out the study were obtained.

- Tool III, the WHOQOL-OLD scale $^{(17)}$, has been validated and tested for reliability by World Health Organization and in many research studies with elders ${ }^{(5,15-20)}$. It was translated into Arabic by the researcher. All rights are reserved by the World Health Organization. In a study carried under the auspices of the World Health Organization Quality of Life Group (WHOQOL Group) in 22 centers from around the world the Cronbach alpha values showed an acceptable range from 0.72 to 0.88 for each facet ${ }^{(18)}$.

- Tool I, II (socio-demographic and clinical data structured interview schedule, health promotion behavior check list) were developed by the researcher based on review of relevant literature.

- A pilot study was carried out on 35 elders to assess the applicability of the tools, these are not included in the study subjects.

- The researcher selected (350 elders) from the 14 centers ( 25 elders from each center). They were chosen from the centers' elderly records randomly by using the systematic sampling technique. The address of each of the selected subject was obtained from the records as well as his telephone number.

- The selected subjects who consented to participate in the study were visited in their own home by the researcher. Each subject was interviewed individually to obtain the necessary data. Information about chronic diseases was obtained from the elder's medical record in the health center.
- Data collection started from the first of December 2019 to the middle of March 2020.

\section{Ethical considerations:}

Informed consent from elders to participate in the study was obtained after explanation of the study purpose. Privacy and confidentiality of the collected data was assured. The elders were also informed about their right to withdraw from the study without penalties.

\section{Statistical Analysis}

Data analysis was carried out with SPSS ${ }^{\circledR} 21.0$ software (SPSS, Chicago, IL, USA). Data are expressed as percentages for discrete variables and as means \pm standard deviations for continuous variables. Pvalues $\leq 0.05$ was considered to be significant. A two-sample $t$ test was performed to compare the mean of the quality of life score in two different groups. An analysis of variance, or ANOVA, to test if there is a difference in means among three or more groups. A multivariate linear regression was performed to determine the independent factors associated with the quality of life of the elders (with the quality of life score as the dependent variable).

\section{Results}

Table (1) shows the socio-demographic characteristics and health status of the study elders. The age of the elders ranged from 65 to 90 years with a mean $72.22 \pm 4.92$ years, in more than half $(51.71 \%)$ were females. More than two fifth $(46.29 \%)$ were married and $(37.14 \%)$ were housewife. As regards educational level (42.29\%) were up to preparatory level. Most elders $(72.86 \%)$ depend on their pension.

It appears from the table that one third (33.43\%0 had vision disorders and only $22.86 \%$ reported hearing disorders. The elders reported having cardiovascular disorders, musculoskeletal disorders, GIT disorders, metabolic disorders as DM, and urinary disorders by $(66.86 \%, 32.29 \%$, 
$25.71 \%, 21.43 \%$, and $15.14 \%$ ) respectively. Also, they reported taking anti-hypertensive (60.17\%), analgesic (28.29\%), diuretic $(26.29 \%)$, digoxin $(26.29 \%)$, hypoglycemic $(22.29 \%)$, and antacid $(18.86 \%)$.

Table (2) shows the QOL status of the study elders. Applying the WHOQOL-OLD on the studied elders, showed that the mean score was $(64.66 \pm 30.52)$ where the QOL status of elders were either very good (10.57\%), good (18.29\%), moderate $(21.14 \%)$, bad $(30.0 \%)$, and very bad (20.0\%).

Table (3) shows the distribution of the study elders according to their health promotion practices. It appears from the table that the main component adopted by elders were psychological and spiritual health practices $(90.0 \%)$ followed by safety environment (82.86\%), avoiding risk behaviors $(74.86 \%)$, consuming proper nutrition $(72.0 \%)$, and having adequate rest and sleep $(70.57 \%)$. Periodic medical checkup, doing physical activities, and participating in social and leisure activities were reported by lower percentages $53.14 \%$, $47.43 \%$, and $43.71 \%$ respectively.

Table (4) shows the relation between the study elders' characteristics and the WHOQOL-OLD score. The elders' QOL status was significantly associated with age, marital status, educational level, source of income, number of diseases, number of drugs, hearing disorders, vision disorders, and health promotion practices $(\mathrm{P}=0.0001)$ for each.

Table (5) shows the multivariate linear regression analyses of the QOL of the study elders' coefficients of each characteristic. The Age $(\mathrm{P}=0.001)$, source of income $(\mathrm{P}=0.0001, \mathrm{P}=0.009)$, number of diseases $(\mathrm{P}=0.0001)$, vision disorder $(\mathrm{P}=0.0001)$ are independent risk factor to decrease QOL. On the other hand, health promotion practice such as participate in physical and social activities $(\mathrm{P}=0.019)$, good nutrition $(\mathrm{P}=0.0001)$, adequate rest and sleep $(\mathrm{P}=0.017)$, maintain periodic medical checkup $\quad(\mathrm{P}=0.038), \quad$ have good psychological and spiritual health $(\mathrm{P}=0.0001, \quad \mathrm{P}=0.054)$, avoid high risk behaviors $(\mathrm{P}=0.036)$, and live in safety environment $(\mathrm{P}=0.019)$ have statistically significant increase in QOL.

\section{Discussion}

The quality of life of elderly people has become relevant with the demographic shift that has resulted in greying of population. The majority of the elderly people evaluate their quality of life positively on the basis of social contacts, dependency, health, material circumstances and social comparisons. Health behaviors play an important role in maintaining good quality of life $\mathrm{e}^{(9,11)}$. Therefore, the aim of the study was to identify the quality of life of community dwelling elderly in Lattakia.

Applying the WHOQOL-OLD on the studied elders revealed that for most of them their QOL reached moderate level and for one fifth of them it was very bad QOL (table 2). The low result of QOL is probably due to that most of them have low income (majority of them depend on pension) which may affect the quality of shelter, nutrition, social participation, household assistance, and acquisition of needed medical care and therapeutic regimen which can lead to inadequate follow up pattern or even neglecting these important issue, this in turn, can affect in a negative way the health and the QOL. As well, lack of financial resources made elders dependent on others which cause loss of control over personal decision-making and fewer choices to master daily life situation. This leads to feeling of decreased personal effectiveness and seem to affect their life satisfaction. Dissatisfaction with life and a lower level of wellbeing, in addition to the insufficient attention to social, psychological, and health care needs usually cause loss of interest, withdrawal, restlessness, feeling downhearted, hopeless and powerlessness. So, all these factors have negative effects on elders' QOL where the source of income affects significantly the elders' QOL (table 4 and 5). 
Nearly one quarter of the elders have hearing and visual disorders which had negative effects on QOL (table 4 and 5). This may be explained by that the elder interacts with the environment by his senses where he can enjoy life more fully when he can see and hear well. As well, it affects his ability to care for himself where poor vision make him unable to read drug instructions and poor hearing affects his social interactions leading to isolation. Moreover, impairment in taste, smell, and touch expose him to danger when he cannot smell gas and the fume and distinguish the spoiled food.

On the other hand, more than one quarter of the elders have good QOL where tenth from them have very good QOL (table 2). This is expected because they live in better conditions, because they have better education and high financial levels that enhance their acquisition to better medical care, follow up, meeting their nutritional needs, engaging in social and recreational activities or volunteer work in the community. This usually raises their self-esteem, influence positively the elders' personality, increase their sense of autonomy leading to life satisfaction. In addition to the increase in social networks, family and friend support, better physical health, all these factors contribute to high QOL. These results supports the findings of other studies done in Brazil (2009) ${ }^{(12)}$, in India $(2010)^{(21)}$, in Brazil $(2013)^{(22)}$, in Taiwan $(2013)^{(23)}$, in Iran (2014) $)^{(7)}$ in Brazil (2016) ${ }^{(14)}$. While contradicts with those of another study done in USA (2012) $)^{(11)}$ where higher figures were reported. This observed difference might be attributed to cultural differences.

A significant relation was noted between health promotion practice and QOL (table 4 and 5). Elders who participate in physical and social activities, maintain periodic medical check up, have good nutrition, adequate rest and sleep, avoid risk behaviors have statistically significant increase in QOL score. This may be attributed to the effect of physical activity which can prevent or delay many of the physical and psychosocial changes associated with aging. It improves overall health status through enhancing better cognitive function and improves overall function, physical fitness, independence in every day activities where it offers a protective effect against functional limitations and increase self-efficacy which in turn, improve mood, promote a sense of well-being, happiness, life satisfaction and active engagement with life. The same was reported in other studies done in USA $(2009)^{(8)}$ and in Brazil (2016) ${ }^{(14)}$.

Family activities, social relationships and increased networks provide the elder with an affirmation of having role in the community and opportunities for reciprocal intimacy and affection which will increase self-esteem and prevent isolation, and helps elders to enjoy their life. As well, the elders' faith and believe in God help them to cope with chronic illness and health problems, adapt to disability, and being satisfied. This is in line with other studies done in USA $(2012)^{(29)}$, in UK $(2014)^{(30)}$, in Japan $(2017)^{(10)}$ which reported that elders with high spirituality had a significant higher QOL.

Moreover, good nutrition is a vital factor for good health where poor nutrition decreases immunity and increases risk of disease. In addition, good sleep is an important index of the QOL. It plays an important role in physical and mental well being as it helps to conserve energy, prevent fatigue, provide organ comfort, relieve tension, and helps in protein synthesis that accelerates tissue repair.

Furthermore, periodic medical check up helps in early identification of diseases leading to early treatment and prevents complications where health prevention and promotion can impede functional decline and offer a better QOL for elderly people. Also, avoiding risk behaviors such as smoking and excessive alcohol use, living in a safety environment protect elders from dangers (table 4 and 5). So, health-promoting lifestyle contributes to a positive QOL because the individual who engages in a health-promoting lifestyle will remain healthy and functional without the burden of disease and disability. The same was reported in a qualitative study done in Canada (2009) ${ }^{(31)}$.

The age of elders of the present study affected significantly their QOL (table 4 and $5)$, this is because of the effect of ageing on factors that influence QOL where advanced 
age is usually associated with limitations in self-care, decreased ability to perform basic tasks, and with increasing age all senses become less acute that increases elders' dependence on others which is thought to lower their QOL. The same findings were reported in Iran study $(2012)^{(24)}$ which revealed a significant correlation between the QOL and age. Also, a study done in Iran $(2016)^{(1)}$ they reported that the age had negative effect on QOL. This contradicts with another study done in Iran (2014) ${ }^{(7)}$ where no significant differences between age and the total score of QOL was observed.

As regards the level of education, very bad QOL was seen clearly among the elders with low education while those with higher education had good QOL (table 4 and 5). This can be attributed to that education help to improve QOL by updating knowledge and improve attitude to health and disease where higher educated elders stick to health promotion components in order to achieve a highly satisfied life. The same findings were reported in another study where literate elderly women had lower mean and higher QOL significantly ${ }^{(1)}$.

The present study revealed that marital status is associated with bad QOL (table 4 and 5). This can be due to the impact of widowhood with its many losses as loss of companionship and intimacy especially among women because of their dependence on their husbands' achievement to provide them with gratification and identity, and some of them become lonely and socially isolated. The same findings were reported in other studies ${ }^{(1,7)}$.

In addition, a significant relation was observed between the increase number of diseases and the QOL. With comorbidities the risk of bad QOL increases (table 4 and 5). This can be due to the fact that chronic comorbidities induce pain and discomfort which affect daily living activities of the elders. Also, it often requires special diet which can affect nutritional status. As well, multiple illnesses usually lead to dependency in daily activities which may lead to relocation, limit personal relationships and cause social isolation, which in turn, cause major sources of stress, depression, anxiety, and other forms of psychological problems in old age that contribute to bad QOL. This result is in line with another study done in Korea $(2006)^{(25)}$ which revealed that perceived health status, number of chronic illnesses, activities of daily living, BP checkup, exercise, and gender were statistically significant predictors of QOL. The same finding was reported in other studies ${ }^{(26,27)}$ which reported that the number of medical conditions emerged as a determinant of health-related and global QOL of elders where mobility, self-care, usual activities, pain and discomfort, and anxiety and depression can be directly affected by medical conditions which in turn affect the QOL. In Iran (2014) ${ }^{(7)}$ a significant difference was observed between having cardiovascular diseases, respiratory and gastrointestinal diseases, hearing and visual impairments with total score of the QOL. In Malaysia (2016) ${ }^{(28)}$ they demonstrated significant associations between chronic diseases, functional disability and the QOL of the elderly.

\section{Conclusion}

It can be concluded from the study that the QOL of most of the community dwelling elders in Lattakia city is moderate. Moreover, QOL of the study elders was affected by age, number of chronic diseases, and health promotion practice.

\section{Recommendations}

- Health centers should schedule assessing elders' QOL as a part of their routine care in order to identify high risk groups for bad quality of life and it should emphases on the importance of practicing health promotion activities in order to improve their QOL.

- Planning policies and programs to improve and promote QOL of elders through establishing governmental or private elderly clubs and information services for educating elderly regarding effective healthy life style to increase QOL.

- Developing community-focused health promotion programs that are directed toward the elderly population indicating that community-based intervention programs targeting these behaviors should be urgently developed by health care professionals. 
Table (1): Distribution of the studied elders according to their socio-demographic characteristics and health status

\begin{tabular}{|c|c|c|}
\hline Socio-demographic Characteristics & $\begin{array}{c}\text { NO. } \\
\text { n=350 }\end{array}$ & $\begin{array}{c}\% \\
100\end{array}$ \\
\hline 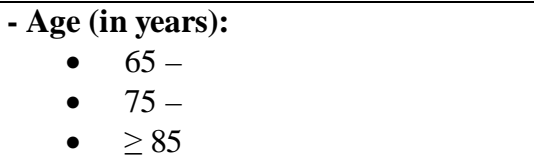 & $\begin{array}{c}270 \\
75 \\
5\end{array}$ & $\begin{array}{c}77.14 \\
21.43 \\
1.43\end{array}$ \\
\hline Mean \pm SD & \multicolumn{2}{|c|}{$72.22 \pm 4.92$} \\
\hline $\begin{aligned} & \text { - Sex: } \\
& \bullet \text { Female } \\
& \bullet \text { Male } \\
&\end{aligned}$ & $\begin{array}{l}181 \\
169 \\
\end{array}$ & $\begin{array}{l}51.71 \\
48.29 \\
\end{array}$ \\
\hline $\begin{array}{cl}\text { - Marital Status: } \\
\text { - } & \text { Married } \\
\text { - } & \text { Widowed } \\
\text { - } & \text { Divorced } \\
\text { - } & \text { Single } \\
\end{array}$ & $\begin{array}{l}162 \\
137 \\
26 \\
25\end{array}$ & $\begin{array}{l}46.29 \\
39.14 \\
7.43 \\
7.14\end{array}$ \\
\hline $\begin{array}{cl}\text { - Educational Level: } \\
\text { - } & \text { Up to preparatory } \\
\text { - } & \text { Secondary } \\
\text { - } & \text { Higher education } \\
\end{array}$ & $\begin{array}{c}148 \\
143 \\
59 \\
\end{array}$ & $\begin{array}{l}42.29 \\
40.86 \\
16.85\end{array}$ \\
\hline $\begin{array}{cl}\text { - Occupation before Retirement: } \\
\text { - } & \text { Housewife } \\
\text { - } & \text { Employee } \\
\text { - } & \text { Technical work } \\
\text { - } & \text { Business (private work) }\end{array}$ & $\begin{array}{l}130 \\
124 \\
77 \\
19\end{array}$ & $\begin{array}{c}37.14 \\
35.43 \\
22.0 \\
5.43\end{array}$ \\
\hline $\begin{array}{l}\text { - Source of income: } \\
\text { - Pension } \\
\text { - } \quad \text { Relative and friends } \\
\text { - } \text { Private properties } \\
\text { - } \text { Social affairs }\end{array}$ & $\begin{array}{c}255 \\
60 \\
30 \\
5\end{array}$ & $\begin{array}{l}72.86 \\
17.14 \\
8.57 \\
1.43\end{array}$ \\
\hline Health Status & & \\
\hline $\begin{aligned} \text { - Hearing disorders: } \\
$\[ \quad \text { No } \]$ \\
\bullet \quad \text { Yes } \\
\end{aligned}$ & $\begin{array}{c}270 \\
80 \\
\end{array}$ & $\begin{array}{l}77.14 \\
22.86 \\
\end{array}$ \\
\hline $\begin{array}{c}\text { - Vision disorders: } \\
\bullet \quad \text { No } \\
\bullet \quad \text { Yes } \\
\end{array}$ & $\begin{array}{l}233 \\
117 \\
\end{array}$ & $\begin{array}{l}66.57 \\
33.43 \\
\end{array}$ \\
\hline $\begin{array}{cl}\text { - Chronic diseases: \# } \\
\text { - None } \\
\text { - } \quad \text { Cardiovascular diseases } \\
\text { - } \text { Musculoskeletal disorders } \\
\text { - } \text { GIT disorders } \\
\text { - } \text { Metabolic disorders(DM) } \\
\text { - } \text { Urinary disorders } \\
\text { - } & \text { Nespiratory disorders } \\
\end{array}$ & $\begin{array}{c}32 \\
234 \\
113 \\
90 \\
75 \\
53 \\
30 \\
18\end{array}$ & $\begin{array}{c}9.14 \\
66.86 \\
32.29 \\
25.71 \\
21.43 \\
15.14 \\
8.57 \\
5.14\end{array}$ \\
\hline $\begin{array}{l}\text { - Medications taken: \# } \\
\text { - None } \\
\text { - Anti-hypertensive } \\
\text { - Anti-inflammatory and analgesics } \\
\text { - Diuretic } \\
\text { - Hypoxin } \\
\text { - Antacid } \\
\text { - Vitamins and minerals } \\
\text { - Laxative } \\
\text { - Antibiotic } \\
\end{array}$ & $\begin{array}{c}24 \\
210 \\
99 \\
92 \\
92 \\
78 \\
66 \\
30 \\
25 \\
24 \\
\end{array}$ & $\begin{array}{c}6.86 \\
60.17 \\
28.29 \\
26.29 \\
26.29 \\
22.29 \\
18.86 \\
8.57 \\
7.14 \\
6.86\end{array}$ \\
\hline
\end{tabular}


Table (2): Distribution of the studied elders according to WHOQOL-OLD scale score

\begin{tabular}{||c|c|c||}
\hline \hline Quality Of Life Status & NO. & \% \\
$\mathbf{n}=\mathbf{3 5 0}$ & $\mathbf{1 0 0}$ \\
\hline - Very good & 37 & 10.57 \\
- good & 64 & 18.29 \\
$\bullet \quad$ Moderate & 74 & 21.14 \\
- bad & 105 & 30.0 \\
\hline Mean score \pm SD & 70 & 20.0 \\
\hline
\end{tabular}

Table (3): Distribution of elders according to their health promotion practice

\begin{tabular}{||l|c|c||}
\hline \hline Health promotion practice\# & NO. & $\mathbf{\%}$ \\
\hline Psychological and spiritual health practices & 315 & $\mathbf{1 0 0}$ \\
Safety environment & 290 & 90.0 \\
Risk behaviors & 262 & 82.86 \\
Proper nutrition & 252 & 74.86 \\
Rest and sleep & 247 & 72.0 \\
Periodic medical check up & 186 & 70.57 \\
Physical activity & 166 & 53.14 \\
Social and leisure activities & 153 & 47.43 \\
\hline
\end{tabular}

\# More than one answer

Table (4): Relation between the studied elders' socio-demographic characteristics, health status and the mean score of WHOQOL-OLD scale

\begin{tabular}{|c|c|c|}
\hline $\begin{array}{l}\text { Quality Of Life } \\
\text { Elders' characteristics }\end{array}$ & $\begin{array}{c}\text { Mean QOL score } \pm \\
\text { SD }\end{array}$ & $P$ value \\
\hline $\begin{array}{c}- \text { Age (in years): } \\
-\quad 65- \\
-\quad 75- \\
\cdot \quad \geq 85 \\
\end{array}$ & $\begin{array}{c}71.20 \pm 30.24 \\
51.03 \pm 26.18 \\
45.0 \pm 27.02\end{array}$ & $\mathrm{P}=0.0001 *$ \\
\hline $\begin{aligned} \text { - Sex: } & \\
\bullet & \text { Female } \\
\bullet & \text { Male }\end{aligned}$ & $\begin{array}{l}64.71 \pm 29.84 \\
64.62 \pm 31.31\end{array}$ & $\mathrm{P}=0.9776$ \\
\hline $\begin{array}{cl}- \text { Marital Status: } \\
\text { - } & \text { Widowed } \\
\text { - } & \text { Divorced } \\
\text { - } & \text { Single } \\
\text { - } & \text { Married }\end{array}$ & $\begin{array}{c}59.91 \pm 27.78 \\
42.46 \pm 24.76 \\
72.0 \pm 24.0 \\
71.11 \pm 32.2\end{array}$ & $\mathrm{P}=0.0001 *$ \\
\hline $\begin{aligned} & \text { - Educational level: } \\
&$\[ \quad \text { Up to preparatory } \]$ \\
& \text { - Secondary } \\
& \text { - } \text { Higher education }\end{aligned}$ & $\begin{array}{l}57.41 \pm 30.10 \\
65.45 \pm 29.21 \\
80.95 \pm 28.50\end{array}$ & $\mathrm{P}=0.0001 *$ \\
\hline $\begin{array}{l}\text { - Source of income: } \\
\text { - Pension } \\
\text { - Relative and friends } \\
\text { - Social affairs } \\
\text { - Private properties }\end{array}$ & $\begin{array}{c}69.27 \pm 30.56 \\
49.60 \pm 27.19 \\
62.40 \pm 36.40 \\
56.0 \pm 24.68\end{array}$ & $\mathrm{P}=0.0001 *$ \\
\hline
\end{tabular}

* Significant $P \leq 0.05$ 


\section{Table (4): Continued}

\begin{tabular}{|c|c|c|}
\hline$\underbrace{\text { Quality Of Life }}_{\text {Elders' characteristics }}$ & $\begin{array}{c}\text { Mean QOL score } \pm \\
\text { SD }\end{array}$ & $P$ value \\
\hline 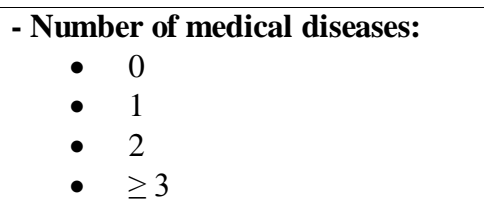 & $\begin{array}{l}108.80 \pm 12.11 \\
71.63 \pm 26.12 \\
60.15 \pm 21.84 \\
37.42 \pm 17.14\end{array}$ & $\mathrm{P}=0.0001 *$ \\
\hline $\begin{aligned} & \text { - Number of Drugs: } \\
&- 0 \\
&- 1 \\
&- 2 \\
&- \geq 3\end{aligned}$ & $\begin{array}{l}99.43 \pm 16.61 \\
74.88 \pm 30.27 \\
65.14 \pm 24.90 \\
43.60 \pm 20.63\end{array}$ & $\mathrm{P}=0.0001 *$ \\
\hline $\begin{array}{l}\text { - Hearing disorders: } \\
\qquad \text { No } \\
\text { • } \quad \text { Yes }\end{array}$ & $\begin{array}{c}69.60 \pm 31.19 \\
48.0 \pm 20.92\end{array}$ & $\mathrm{P}=0.0001 *$ \\
\hline $\begin{array}{c}\text { - Vision disorders: } \\
\qquad \text { No } \\
\bullet \quad \text { Yes } \\
\end{array}$ & $\begin{array}{l}74.06 \pm 30.16 \\
45.95 \pm 21.27\end{array}$ & $\mathrm{P}=0.0001 *$ \\
\hline 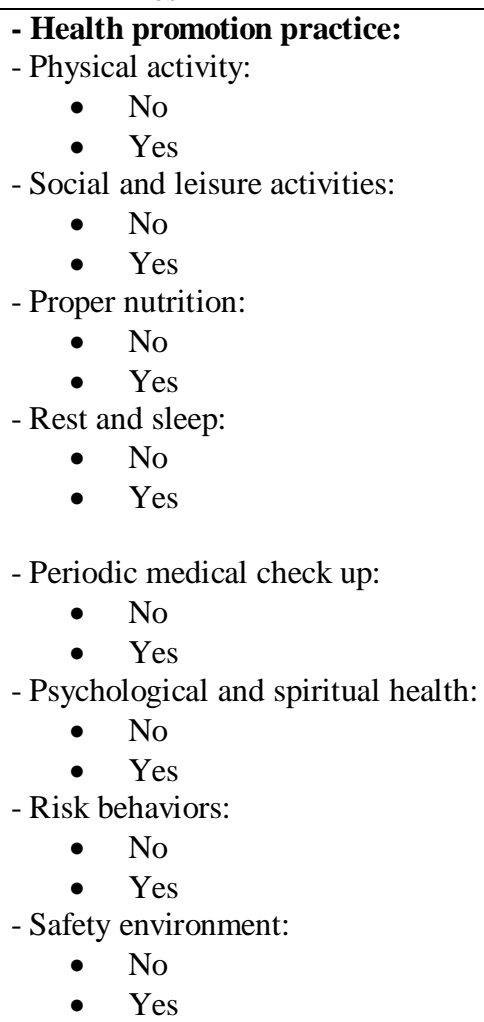 & $\begin{array}{r}49.96 \pm 22.28 \\
80.96 \pm 30.18 \\
50.19 \pm 22.24 \\
83.29 \pm 29.66 \\
44.82 \pm 22.24 \\
72.38 \pm 29.84 \\
48.23 \pm 20.85 \\
71.51 \pm 31.32 \\
\\
49.61 \pm 22.42 \\
77.94 \pm 30.59 \\
\\
43.20 \pm 20.83 \\
67.05 \pm 30.51 \\
84.82 \pm 30.0 \\
57.89 \pm 27.61 \\
43.60 \pm 17.94 \\
69.02 \pm 30.79\end{array}$ & $\begin{array}{l}\mathrm{P}=0.0001 * \\
\mathrm{P}=0.0001 * \\
\mathrm{P}=0.0001 * \\
\mathrm{P}=0.0001 *\end{array}$ \\
\hline
\end{tabular}

* Significant $P \leq 0.05$ 
Table (5): Multivariate linear regression analyses of the quality of life of the study elders' coefficients of each characteristic

\begin{tabular}{|c|c|c|c|c|}
\hline Quality Of Life & $\begin{array}{l}\text { Coef. Of } \\
\text { regression }\end{array}$ & $P$ value & $95 \%$ & terval \\
\hline $\begin{array}{l}\text { - } 65- \\
\text { - } 75- \\
\text { - } \geq 85\end{array}$ & $\begin{array}{c}\text { Reference } \\
-6.97 \\
-4.27\end{array}$ & $\begin{array}{c}\mathrm{P}=0.001^{*} \\
\mathrm{P}=0.448\end{array}$ & $\begin{array}{l}-11.16 \\
-15.35\end{array}$ & $\begin{array}{c}-2.77 \\
6.80\end{array}$ \\
\hline - Sex: $(\bar{M})$ & -0.75 & $\mathrm{P}=0.786$ & -6.20 & 4.70 \\
\hline $\begin{array}{cl}\text { - Marital Status: } \\
\text { - } & \text { Widowed } \\
\text { - } & \text { Divorced } \\
\text { - } & \text { Single } \\
\text { - } & \text { Married }\end{array}$ & $\begin{array}{c}\text { Reference } \\
0.17 \\
7.11 \\
-3.51\end{array}$ & $\begin{array}{l}0.947 \\
0.314 \\
0.341\end{array}$ & $\begin{array}{l}-4.72 \\
-6.76 \\
-10.75\end{array}$ & $\begin{array}{c}5.05 \\
20.99 \\
3.73\end{array}$ \\
\hline $\begin{array}{cl}\text { - Educational level: } \\
\text { - } & \text { Up to preparatory } \\
\text { - } & \text { Secondary } \\
\text { - } & \text { Higher education } \\
\end{array}$ & $\begin{array}{c}\text { Reference } \\
-2.76 \\
-2.0 \\
\end{array}$ & $\begin{array}{l}\mathrm{P}=0.152 \\
\mathrm{P}=0.447\end{array}$ & $\begin{array}{l}-6.53 \\
-7.17 \\
\end{array}$ & $\begin{array}{l}1.02 \\
3.17 \\
\end{array}$ \\
\hline $\begin{array}{l}\text { - Occupation before retirement: } \\
\text { - Housewife } \\
\text { - Employee } \\
\text { - Business } \\
\text { - Technical worker }\end{array}$ & $\begin{array}{c}\text { Reference } \\
-0.47 \\
1.42 \\
-4.43 \\
\end{array}$ & $\begin{array}{l}0.876 \\
0.781 \\
0.175\end{array}$ & $\begin{array}{l}-6.46 \\
-8.63 \\
-10.83 \\
\end{array}$ & $\begin{array}{c}5.52 \\
11.47 \\
1.98\end{array}$ \\
\hline $\begin{array}{l}\text { - Source of income: } \\
\text { - Pension } \\
\text { - Relative and friends } \\
\text { - Social affairs } \\
\text { - Private properties } \\
\end{array}$ & $\begin{array}{c}\text { Reference } \\
-14.09 \\
8.93 \\
2.75 \\
\end{array}$ & $\begin{array}{c}\mathrm{P}=0.0001 * \\
\mathrm{P}=0.009^{*} \\
\mathrm{P}=0.225\end{array}$ & $\begin{array}{l}-21.18 \\
2.24 \\
-1.70 \\
\end{array}$ & $\begin{array}{c}-7.0 \\
15.62 \\
7.21 \\
\end{array}$ \\
\hline $\begin{aligned} \text { - Number of diseases: } & \\
- & 0 \\
- & 1 \\
- & 2 \\
- & \geq 3\end{aligned}$ & $\begin{array}{l}\text { Reference } \\
-14.79 \\
-24.67 \\
-37.22\end{array}$ & $\begin{array}{l}\mathrm{P}=0.0001 * \\
\mathrm{P}=0.0001 * \\
\mathrm{P}=0.0001 *\end{array}$ & $\begin{array}{l}-20.56 \\
-31.07 \\
-44.76\end{array}$ & $\begin{array}{l}-9.01 \\
-18.27 \\
-29.68\end{array}$ \\
\hline - Hearing disorders & -0.11 & $\mathrm{P}=0.959$ & -4.35 & 4.12 \\
\hline - Vision disorders & -7.77 & $\mathrm{P}=0.0001^{*}$ & -11.80 & -3.74 \\
\hline - Mobility problems & -0.71 & $\mathrm{P}=0.767$ & -5.41 & 3.99 \\
\hline $\begin{array}{l}\text { - Health promotion practice: } \\
\text { - Physical activity } \\
\text { - Social and leisure activities } \\
\text { - Nutrition } \\
\text { - Rest and sleep } \\
\text { - Periodic medical check up } \\
\text { - Psychological and spiritual health } \\
\text { - High risk behaviors } \\
\text { - Safety environment }\end{array}$ & $\begin{array}{c}4.80 \\
16.54 \\
4.94 \\
4.10 \\
9.94 \\
5.52 \\
5.05 \\
-5.05\end{array}$ & $\begin{array}{c}\mathrm{P}=0.019^{*} \\
\mathrm{P}=0.0001^{*} \\
\mathrm{P}=0.017^{*} \\
\mathrm{P}=0.038^{*} \\
\mathrm{P}=0.0001^{*} \\
\mathrm{P}=0.054^{*} \\
\mathrm{P}=0.036^{*} \\
\mathrm{P}=0.019^{*}\end{array}$ & $\begin{array}{c}0.78 \\
12.69 \\
0.91 \\
0.23 \\
6.23 \\
-0.09 \\
0.34 \\
-9.28\end{array}$ & $\begin{array}{c}8.83 \\
20.38 \\
8.97 \\
7.98 \\
13.66 \\
11.13 \\
9.75 \\
-0.82\end{array}$ \\
\hline
\end{tabular}




\section{References}

1. Maleki F, Aghdam M, Hosseinpour M. Socioeconomic status and quality of life in elderly neglected people in rural area of western Iran. J Curr Res Sci 2016; 4 (3): 89- 93.

2. Melo R, Júnior E, Souto R, Leāo Í, Eulálio M. Psychometric properties of the complete version of the World Health Organization Quality of Life Assessment (WHOQOLOLD): reduced response scale. Psicologia: Reflexāo e Critica 2018; 31 (4): 1- 10.

3. European Research Area in Ageing 2010. Available at: http://www.eraage.group.shef.ac.uk/. Retrieved on: 3/2/2019.

4. WHO. WHOQOL Group, 1995. Available at:

https://apps.who.int/iris/rest/bitstreams/110 129/retrieve. Retrieved on: 3/2/2019.

5. Faculty of Medicine, University of Oslo. Measuring quality of life among older adults: validation of the Norwegian WHOQOL-OLD. Liv Halvorsrud, 2010.

6. Tsuji-Hayashi Y, Young B, Green J, Tsuji A, Hosoya T, Fukuhara S, Blagg C. Healthrelated quality of life among communitydwelling elderly people in the general populations of the US and Japan. JMAJ 2005; 48 (10): 489- 96.

7. Khaje-Bishak Y, Payahoo L, Pourghasem B, Jafarabadi M. Assessing the quality of life in elderly people and related factors in Tariz, Iran. Journal of Caring Sciences 2014; 3(4): 257- 63.

8. White S, Wójcicki T, McAuley E. Physical activity and quality of life in community dwelling older adults. Health and Quality of Life Outcomes 2009; 7 (10): 1- 7.

9. Netuveli G, Blane D. Quality of life in older ages. British Medical Bulletin 2008; 85 (1): 113- 26.

10. Kobayashi M, Marui E. Factors affecting the health-related quality of life of community-dwelling elderly in Japan: a focus on spirituality. Health 2017; 9: 1095111.

11. Baernholdt M, Hinton I, Yan G, Rose K, Mattos M. Factors associated with quality of life in older adults in the United States. Qual Life Res 2012; 21 (3): 527- 34.
12. Figueira H, Giani T, Beresford H, Ferreira M, Mello D, Figueira A, Figueira J, Dantas E. Quality of life (QOL) axiological profile of the elderly population served by the Family Health Program (FHP) in Brazil. Archives of Gerontology and Geriatrics 2009; 49: 368- 72.

13. Mangen $M$, Bolkenbaas $M$, Huijts $S$, Werkhoven C. Quality of life in community-dwelling Dutch elderly measured by EQ-5D-3L. Health and Quality of Life Outcomes 2017; 15 (3): 16.

14. Miranda L, Soares S, Silva P. Quality of life and associated factors in elderly people at a Reference Center. Ciência \& Saúde Coletiva 2016; 21 (11): 3533- 44.

15. Liu R, Wu S, Hao Y, Gu J, Fang J, Cai N, Zhang J. The Chinese version of the world health organization quality of life instrument-older adults module (WHOQOL-OLD): psychometric evaluation. BioMed Central Health and Quality of Life Outcomes 2013; 11 (156): 1-8.

16. Eser S, Saatli G, Eser E, Baydur H, Fidaner C. The reliability and validity of the Turkish version of the world health organization quality of life instrument-older adults module (WHOQOL-OLD). Turkish Journal of Psychiatry 2010; 21 (1): 1- 10.

17. WHOQOL-OLD Manual. European Office (Copenhagen): World Health Organization; 2006. (May 2006)

18. Power, Quinn K, Schmidt S, The WHOQOL-OLD Group. Development of the WHOQOL-OLD module. Quality of Life Research 2005; 14 (2005): 2197- 214.

19. Chachamovich E, Fleck M, Trentini C, Power M. Brazilian WHOQOL-OLD module version: a rasch analysis of a new instrument. Rev Saúde Pública 2008; 42 (2): $308-16$

20. Fang J, Power M, Lin Y, Zhang J, Hao Y, Chatterji S. Development of short versions for the WHOQOL-OLD module. The Gerontologist 2011; 52 (1): 66- 78.

21. Varma G.R, Kusuma Y.S, Babu BV. Health-related quality of life of elderly living in the rural community and homes for the elderly in a district of India. 
Zeitschrift für Gerontologie und Geriatrie 2010; 4: 259- 63.

22. Vitorino L, Paskulin L, Vianna L. Quality of life of seniors living in the community and in long term care facilities: a comparative study. Rev Latino-Am Enfermagem 2013; 21 (Spec): 3-11.

23. Wu T, Chie W, Kuo K, Wong W, Liu J, Chiu S, Cheng Y, Netuveli G, Blane D. Quality of life (QOL) among community dwelling older people in Taiwan measured by the CASP-19, an index to capture QOL in old age. Archives of Gerontology and Geriatrics 2013; 57 (2013): 143-50.

24. Heydari J, Rouhani S, Mohammadpour RA. Aging populations' quality of life: an emerging priority for public health system in Iran. Life Science Journal 2012; 9 (4): 1304- 9.

25. Lee T, Ko I, Lee $\mathrm{K}$. Health promotion behaviors and quality of life among community-dwelling elderly in Korea: a cross-sectional survey. International Journal of Nursing Studioes 2006; 43 (2006): 293- 300.

26. Marengoni A, Angleman S, Melis R, Mangialasche F, Krap A, Garmen A, Meinow B, Fratiglioni L. Aging with multimorbidity: a systematic review of literature. Ageing Research Reviewrs 2011; 10 (4): 430- 9.
27. Martinez-Martin P, Prieto-Flores M, Forjaz M, Fernandez-Mayoralas G, Rojo-Perez F, Rojo J, Ayala A. Components and determinants of quality of life in community-dwelling older adults. European Journal of Ageing 2012; 9 (3): 255- 63.

28. Onunkwor O, Al-Dubi S, George P, Arokiasamy J, Yadav H, Barua A, Shuaibu H. A cross-sectional study on quality of life among the elderly in non-governmental organizations' elderly homes in Kuala Lumpur. Health and Quality of Life Outcomes 2016; 14 (6): 1- 10.

29. Konopack J.F, McAuley E. Efficacymediated effects of spirituality and physical activity on quality of life: a path analysis. Health and Quality of Life Outcomes 2012; 10 (57): 1- 6. https://doi.org/10.1186/14777525-10-57

30. Parker L, Moran GM, Roberts LM, Calvert M, McCahon D. The burden of common chronic disease on health-related quality of life in an elderly community-dwelling population in the UK. Family Practice 2014; $31 \quad$ (5): $\quad$ 557- 63. https://doi.org/10.1093/fampra/cmu035

31. Levasseur M, Tribble D, Desrosiers J. Meaning of quality of life for older adults: importance of human functioning components. Archives of Gerontology and Geriatrics 2009; 49 (2009): 91- 100. 